TOMASZ BORGUL, TOMASZ PANEK

Instytut Politologii UO

\title{
Merytokracja i technokratyzm - o niepolitycznych tendencjach hegemonicznych zdefektowanego liberalizmu
}

$\mathbf{N}$ iniejszy artykuł jest próbą zmierzenia się z możliwymi zagrożeniami demokracji liberalnej, która - m.in. z powodu wewnętrznego kryzysu narażona jest na wiele niebezpieczeństw, rozsadzających demokratyczne struktury państwa. Kryzys wartości demokratyczno-liberalnych może stanowić źródło rozlicznych niestabilności, zagrażających ideologicznemu „porządkowi”. Jednym z możliwych kierunków regresji tegoż ładu mogłyby być dyskursy: technokratyczny, a w postaci „ideowo zaawansowanej” - merytokratyczny. Gdyby technokratyzm oraz merytokratyzm potraktować jako alternatywę wartości liberalnych, ich legitymizacji należałoby z pewnością poszukiwać w ramach zaistniałej sytuacji kryzysowej dotychczasowego modelu polityczno-gospodarczego. Ideologiczna transformacja doprowadziłaby więc do zanegowania systemu liberalnego oraz wartości przezeń reprezentowanych na rzecz rozwiązań reorganizujących nie tylko kategorię systemu politycznego, ale również społeczny sposób myślenia o rzeczywistości.

Jednym z potencjalnych zagrożeń demokracji liberalnej staje się obecnie globalny kryzys gospodarczy wywołany przez „nieomylną” doktrynę ekonomiczną neoliberalizmu. Intensywnie propagowany i wspierany przez demokracje liberalne początków lat 90. nowy reengineering gospodarczy, wymagający m.in. „pogłębienia kapitalistycznej logiki poszukiwania zysku w stosunkach kapitał-siła robocza; podniesienia wydajności siły roboczej 
i kapitału; globalizacji produkcji, wymiany i rynków, [...] oraz zdobywania poparcia państwa dla wzrostu wydajności i konkurencyjności narodowych gospodarek", doprowadził do rozległego paraliżu gospodarek światowych. Już u schyłku wielkiego kryzysu gospodarczego przełomu lat 20. i 30. XX wieku Friedrich Pollock wskazywał na niebezpieczeństwa funkcjonowania liberalnej logiki rynkowej. Alarmował zarówno ortodoksyjnych liberałów, jak i społeczeństwo, iż należy się „liczyć nie tylko z kryzysami mającymi tendencje do pogłębiania się, ale także z szybszym ich następowaniem po sobie z racji coraz silniejszego przyspieszania tych procesów produkcyjnych, które decydują o toku koniunktury" ${ }^{2}$. Destruktywne skutki cykliczności kryzysów gospodarczych, mimo że zgodnie z założeniami neoliberalnej ekonomii są oczywistym prawem, mogą stać się zarzewiem nowych konfliktów społeczno-politycznych, będących źródłem niestabilności systemu współczesnych demokracji zachodnich. Deregulatywnej roli globalnych rynków w kontekście funkcjonowania demokracji liberalnych nie sposób nie przeceniać. Skutki tak funkcjonującego neoliberalizmu mogą wyrządzić nieodwracalne szkody zarówno w sferze społecznej, jak i politycznej. W sytuacji, w której „mechanizm gospodarczy kierowany przez bezosobowe siły rynkowe zdaje się, mniejsza czy słusznie, wymykać kontroli, narasta poczucie strachu. Wszystko jawi się jako potencjalna groźba. Stąd nowe lęki i nowe skażenia korodujące zarówno więź społeczną, jak i formy życia demokratycznego. Kłopoty z tożsamością nakładają się na oczywistości życia politycznego i powodują prawdziwy krach polityki" ".

Neoliberalizm staje się również inspiracją niebezpiecznych tendencji redukcjonistycznych w obrębie swobód jednostek oraz zagraża ich tożsamości w zakresie niepozwalającym im na przejrzystą identyfikację społeczną. Słabości demokracji liberalnej, która nie bardzo wie, jak poradzić sobie z neoliberalną siłą, z pewnością można uznać za przyczynę ograniczonej ochrony wolności w obszarze prywatnym. Marcin Król wskazuje na paradoks równoległej egzystencji demokracji liberalnej oraz neoliberalizmu, traktowanego podług doktrynalnych założeń tej pierwszej, jako element zagrażający wolności jednostek „w sferze prywatnej, bo postuluje nieograniczony wzrost gospodarczy nawet kosztem ograniczenia innych wolności, której gwarantem jest liberalizm" ${ }^{4}$. Bezsprzecznie ideologiczna teza Francisa Fukuyamy o końcu historii, traktująca nie tylko demokrację liberalną, ale - co

M. Castells, Wiek informacji, t. I, Społeczeństwo sieci, Warszawa 2007, s. 35.

F. Pollock, Uwagi o kryzysie gospodarczym, [w:] Szkoła Frankfurcka, t. I, cz. II, red. J. Łoziński, Warszawa 1985, s. 286.

J. P. Fitoussi, Czas nowych nierówności, Kraków 2000, s. 48.

M. Król, Bezradność liberałów. Myśl liberalna wobec konfliktu i wojny, Warszawa 2005, s. 52. 
wymaga podkreślenia - również neoliberalny porządek jako formy najdoskonalszych rozwiązań, chwieje się w swych posadach, gdy adwersarze zrzucają zasłony jej sędziwych iluzji i wewnętrznych sprzeczności. Neoliberalna potęga nie zawsze potrafi zatuszować skutki swego destruktywnego działania. Gdy tylko współczesny kapitalizm globalny uczynimy nieco bardziej transparentnym, stwierdzić należy że „uniezależnił się od jakiegokolwiek systemu ludzkich wartości i zastąpił je wymogami poddania się rzekomym prawom rynku" ${ }^{5}$. Sfera wartości społecznych zostaje poddana ekskluzji już w łonie samego systemu, którego nie stać na utrzymywanie „moralnych luksusów". Stąd też rozrastający się z ogromną siłą kryzys społecznych tożsamości.

Pomimo wspomnianej równoległej egzystencji demokratycznej formy państwa z promowanym przez nią systemem gospodarczym neoliberalizm usamodzielnił się w stopniu niebezpiecznie zagrażającym demokracji liberalnej. Zawłaszczył bowiem sferę polityki na poziomie wykluczającym realny wpływ obywateli na losy ich kraju, gdyż coraz częściej „o kondycji gospodarki decydują czynniki pozapolityczne" . Globalne korporacje stają się jednymi z najpotężniejszych graczy nie tylko w sferze gospodarki, ale również polityki. Naomi Klein stwierdza więc z ironią godną zatroskanego o losy swojego kraju obywatela: „Jakiż pożytek z obradującego jawnie i odpowiadającego przed obywatelami parlamentu czy kongresu, jeśli za kulisami nieprzejrzyste korporacje ustalają światowy program polityczny?" ${ }^{7}$. Czy zatem demokracja liberalna, pozbawiona skutecznych narzędzi politycznych, przestaje mieć realny wpływ na całokształt współczesnych stosunków społecznogospodarczych? Czy wreszcie alternacja władzy, będąca immanentnym procesem współczesnej demokracji, pozostaje w tej perspektywie jedynie rodzajem subtelnej iluzji, «oktrojowanej» przez neoliberalny porządek gospodarczy? Norberto Bobbio miał rację, nazywając neoliberalizm „konsekwentną teorią ekonomiczną", . Już od początków ubiegłego wieku doktryna neoliberalna wykazywała określone słabości, wyraźnie nie radząc sobie ze sferą rozrastającej się do monstrualnych rozmiarów własności prywatnej, reprezentowanej przez trusty oraz koncerny transnarodowe. Sfera kapitalizmu monopolistycznego z racji swojej nieelastyczności produkcyjnej, polegającej na niemożności przystosowania się do warunków kryzysu gospodarczego, zawsze mogła i nadal może - w ramach tzw. „kultury kryzysu” - liczyć na

\footnotetext{
A. Samin, Wirus liberalizmu, Warszawa 2007, s. 84.

Tamże, s. 75.

N. Klein, No Logo, Izabelin 2004, s. 359; taż, Doktryna szoku. Jak wspótczesny kapitalizm wykorzystuje klęski żywiołowe $i$ kryzysy społeczne, Warszawa 2009, s. 319-361.

N. Bobbio, Liberalizm i demokracja, Kraków 1998, s. 59.
} 
państwową pomoc. Demokracje liberalne, dla których jawnym zagrożeniem jest rozwijany w oparciu o neoliberalne ,prawdy” międzynarodowy kapitał, stosują w momentach kryzysu gospodarczego prawa systemu (alokacja miliardowych dotacji $\mathrm{w}$ nierentowne sektory), walnie przyczyniającego się przecież do deregulacji ich narodowych gospodarek. Monopolistyczny kapitalizm globalny przejmuje w tym kontekście kontrolę nad strukturą współczesnego państwa, uniemożliwiając mu, notabene na jego własne życzenie, efektywną kontrolę w sferze polityki. Innymi słowy to właśnie przynależne aparatowi państwowemu „struktury władzy, które tradycyjnie ułatwiały działanie kapitalistom, ustalając korzystne dla nich prawa i dbając o ich funkcjonowanie, stają się coraz mniej wydajne i cieszą się coraz mniejszym uznaniem w oczach obywateli. Stosując neoliberalną politykę, a więc obcinając wydatki i wycofując się z gospodarki, rządy państwowe same ograniczają swoje wpływy".

Sukcesywnej erozji ulega również - wypracowany w kręgu cywilizacji Zachodu - konstrukt państwa narodowego. Jak zauważa Seyla Benhabib: „Począwszy od wieku XVII, demokratyzacja postępowała krok w krok z procesem konsolidacji nowoczesnego państwa narodowego: te dwa procesy wydawały się chwilami przebiegać w przeciwległych kierunkach, zazwyczaj jednak uzupełniały się nawzajem. [...] Wraz z rozszerzaniem się zakresu formalnego obowiązywania praw obywatelskich dokonywało się ich wzbogacenie: od wolności osobistej i praw obywatelskich poprzez prawa polityczne do praw socjalnych. Ideał samorządności coraz powszechniej pojmowany był jako formalna równość obywateli należących do demos, zaś jednakowy udział w wolnościach stał się odtąd równoznaczny z udziałem w dostępnych prawach [...] i z możliwością ich praktykowania. Obywatelsko-republikański ideał samorządności (czyli doświadczenie udziału z równymi sobie w przestrzeni publicznej) okazał się zatem $\mathrm{w}$ istocie nieodwołalnie powiązany z liberalnym ideałem obywatelstwa (citizenship), czyli praktykowaniem istniejących praw, możliwości i przywilejów. Demokracje naszych czasów dążą więc do tych dwóch ideałów - republikańskiego i demokratycznego - co przekłada się na możliwość korzystania z dwóch postaci autonomii: «prywatnej» $\mathrm{i}$ «publicznej». [...] gdy «autonomia prywatna» zakłada doświadczenie i praktykowanie wolności poprzez system praw (rights-framework), leżący u podstaw zjawiska jednakowego udziału w wolnościach, to autonomia publiczna urzeczywistnia się poprzez instytucje demokratycznego samorzą-

E. Majewska, J. Sowa, Od redaktorów. Neoliberalizm - petryfikacja wyobraźni, [w:] Zniewolony umyst. Neoliberalizm i jego krytyki, red. E. Majewska, J. Sowa, Kraków 2007, s. 10. 
du w coraz bardziej złożonych społecznościach" ${ }^{, 10}$. Niestety powyższy model ustrojowy, „stosunkowo udane połączenie ideału republikańskiego i liberalno-demokratycznego, synteza autonomii prywatnej i publicznej przechodzi obecnie kryzys" ${ }^{, 11}$. „Postwestfalska” ${ }^{12}$ idea niepodzielnej suwerenności państwa (terytorialnej, administracyjno-kontrolnej, kulturowej, legitymizacyjnej) ulega znaczącym modyfikacjom pod wpływem następujących czynników: wymienionych już perturbacji ekonomicznych, „prywatyzacji” przymusu państwowego i domeny militarnej państwa, kategorii „zróżnicowanego obywatelstwa” oraz „kosmopolitycznego federalizmu”, okcydentalnej (euroatlantyckocentrycznej) wizji relacji międzycywilizacyjnych, emancypacji grup subnarodowych, ponadnarodowego terroryzmu o właściwościach ludobójczych oraz masowych ruchów migracyjnych ${ }^{14}$.

Powyższe procesy, o charakterze zarówno społeczno-politycznym, jak i gospodarczym, wyraźnie deregulują konsensus liberalno-demokratyczny. Mogą one stać się punktem wyjścia do kreowania nowych dyskursów ideowych, reorganizujących dotychczasowy porządek. Podstawowe pytanie dotyczy więc formy stosunków polityczno-gospodarczych przyszłości oraz ich treści. Problemem jest po pierwsze to, w jaki sposób demokracje liberalne zareagują na kolejny kryzys strukturalny naszego stulecia, po drugie zaś jak społeczeństwo zachowa się w ocenie klasy politycznej, niewątpliwie odpowiedzialnej za stan obecny.

Czy wobec wielkości kryzysu, nie tylko niszczącego narodowe gospodarki, ale również dezintegrującego liberalne demokracje możliwy jest nowy paradygmat myślowy, „efektywniej” organizujący rzeczywistość polityczno-

${ }^{10}$ S. Benhabib, Kryzys państwa narodowego. Granice tożsamości obywatelskiej, „Przegląd Polityczny" 2003, nr 62/63, s. 154.

Tamże.

12 Chodzi tutaj o odniesienie do europejskiego konfliktu religijnego zwanego wojną trzydziestoletnią (1618-1648) oraz kończącego go traktatu westfalskiego, wyznaczającego aż do czasów współczesnych (do wybuchu I wojny światowej) kanony myślenia o suwerenności państwowej i stosunkach międzynarodowych; szerzej zob. A. Gałganek, „Westfalia” jako metafora genezy w nauce o stosunkach międzynarodowych, [w:] Późnowestfalski ład międzynarodowy, red. M. Pietraś, K. Marzęda, Lublin 2008, s. 23-56.

13 Pierwsza z nich dotyczy partycypacji w życiu wspólnoty demokratycznej, druga natomiast odnosi się do wzajemnego oddziaływania trans- i międzynarodowych norm prawnych czy inicjatyw ciał ustawodawczych określonych państw.

S. Benhabib, Kryzys państwa narodowego, s. 154-161; P. Frankowski, Ponowoczesne „państwo" i jego miejsce w wyłaniającym się ładzie międzynarodowym, [w:] Późnowestfalski ład międzynarodowy, s. 335-345; G. Gil, Ewolucja państwa w późnowestfalskim tadzie międzynarodowym, [w:] Późnowestfalski ład międzynarodowy, s. 372-381; T. Kuczur, Przyszłość państwa narodowego we wspótczesnym globalnym układzie międzynarodowym, „Gdańskie Studia Międzynarodowe” 2007, nr 1-2, s. 29-38; M. Lorenc, Zakres suwerenności państwa we wspótczesnym świecie, [w:] Późnowestfalski ład międzynarodowy, s. 357-364; A. Nogal, Zmierzch państwa narodowego, [w:] Filozofia wobec XXI wieku, red. L. Gawor, Lublin 2004, s. 77-82. 
gospodarczą? Czy mógłby zatem zaistnieć - używając języka Chantal Mouffe oraz Ernesta Laclau - rodzaj kontrhegemonicznego dyskursu ${ }^{15}$, zdolnego zagrozić obecnej formule demokracji liberalnej oraz doktrynie neoliberalnej? Czy wreszcie siła owego dyskursu zdolna jest zetrzeć „ideologie oczywistości”, proponując jednocześnie „skuteczną” alternatywę? Jak pokazuje doświadczenie przeszłości, w momencie największego zagrożenia jednostki w dużej mierze organizują swoje myślenie i działanie wokół ideologicznych struktur systemu, w którym się poruszają. Społeczeństwu znacznie trudniej przychodzi negacja istniejącego stanu rzeczy, wyrażająca się w postawie rewolucyjnej postulującej odrzucenie neoliberalnych „prawd”, niż akceptacja „kryzysowego” systemu. Cykliczność gospodarczych krachów, wpisanych w ideologiczną strukturę „opium" neoliberalizmu, stała się częścią społecznej racjonalności, uzasadniającej status quo. Tego rodzaju ujęcie tożsame jest z Marksowską koncepcją ideologii, w ramach której „formy świadomości społecznej" ${ }^{, 17}$ odpowiadają strukturze nadbudowy reprezentowanej przez system prawny oraz polityczny. Truizmem byłoby jednak twierdzenie, że system nie akomoduje się, pozostaje bierny wobec złożonych warunków, w jakich przyszło mu funkcjonować. Jeżeli zatem możliwa jest reprodukcja, to możliwa jest też zmiana jej towarzysząca. Według Andrew Heywooda liberalizm nie funkcjonuje w globalnej próżni ideologicznej, pozbawiony bowiem przymiotów uniwersalizmu, stanowi jedynie pewien możliwy sposób organizacji oraz rozwoju. Zawsze istnieje potencjalna możliwość odwrotu społeczeństwa od ideologicznego porządku ${ }^{18}$.

Jednym z przykładów takiego odwrotu, mógłby być nowy, formujący się dyskurs kontrhegemoniczny, reprezentujący cechy systemu technokratycznego, a być może nawet merytokratyzmu. Żaden z „oczywistych” porządków nie może istnieć w postaci trwałej struktury, ponieważ zawsze jest wynikiem walk hegemonicznych, a „pojęcie hegemonii wypełnia przestrzeń opustoszałą w wyniku kryzysu czegoś, co zgodnie z «koncepcją stadiów» Plechanowa powinno być normalnym historycznym rozwojem. Dlatego zhegemonizowanie pewnego zadania bądź układu sił politycznych należy do obszaru historycznej przygodności" ${ }^{19}$. Zgodnie z przedstawioną teorią istnienie platformy agonistycznej, w ramach której dokonuje się renegocjacji dotychczasowych konceptów politycznych i społecznych, możliwe jest dopóty, do-

\footnotetext{
E. Laclau, Ch. Mouffe, Hegemonia i socjalistyczna strategia. Przyczynek do projektu radykalnej polityki demokratycznej, Wrocław 2007.

J. Żakowski, Zakony kapitalizmu, „Polityka” 2009, nr 21, s. 38-43.

K. Marks, Przyczynek do krytyki ekonomii politycznej, Warszawa 1955, s. 5.

A. Heywood, Ideologie polityczne. Wprowadzenie, Warszawa 2007, s. 80.

E. Laclau, Ch. Mouffe, Hegemonia i socjalistyczna strategia, s. 53.
} 
póki istnieją sprzeczne interesy wielu grup uformowanych często na różnych biegunach myślowych.

Pomimo faktu, iż „neoliberalna propaganda stara się zniewolić umysł I zaaresztować wyobraźnię tak, aby społeczno-ekonomiczne status quo nie było poddawane krytyce i aby nie szukać dla niego alternatyw" ${ }^{20}$, rozsądne wydaje się stwierdzenie, że petryfikacja rzeczywistości za pomocą ideologicznego instrumentarium neoliberalizmu nie jest ostatecznie przesądzona. Możliwa jest opozycja, nierzadko wyrastająca na poważną siłę polityczną, ponieważ demokracja liberalna pomimo swego kryzysu ciągle gwarantuje płaszczyznę agonizmu, na gruncie której wyrastają dyskursy opozycyjne zarówno wobec siebie, jak i aktualnego stanu rzeczy ${ }^{21}$. Dotychczasowe jednak relacje pomiędzy kierunkiem politycznego zarządzania państwem a elementami zewnątrzsystemowymi nie zdały egzaminu, czego implikacją jest przywoływany częstokroć wielopłaszczyznowy kryzys struktur państwa oraz gospodarki. Systemem znakomicie odgrywającym rolę radykalnej koncepcji redukującej znaczenie „zepsutego pierwiastka” polityki mógłby być właśnie pragmatyczny technokratyzm. Sprzężony z rudymentami systemu technokratycznego pragmatyzm ufundowany, jak ująłby to Harry K. Wells, na platformie „oportunizmu skuteczności” - jednej z pragmatycznych metod w sposób doskonały urzeczywistniałby idee technokratycznej formy organizacji państwa. „Oznacza on [oportunizm skuteczności] korzystanie z wszelkich środków, jakie tylko mogą się przydać do osiągnięcia upragnionego celu. Każdy środek jest «dobry», jeżeli jest skuteczny, jeżeli «działa»; natomiast jest zły, jeżeli zawodzi, jeżeli «nie działa»"22. Rozkład tradycyjnie rozumianej polityki, będącej w coraz większym stopniu narzędziem w realizacji partykularyzmów rządzących, oderwanie sfery polityki od społeczeństwa oraz brak zaufania do elit politycznych - to tylko niektóre z objawów politycznego fin de siècle, mogące stanowić doskonały grunt do rozwoju tendencji technokratycznych. Mogłyby one znaleźć oparcie m.in. w generalnym zniechęceniu społeczeństwa do elit politycznych oraz sukcesywnym zaniku form aktywności obywatelskiej w sferze politycznej. Potencjalny kierunek regresji porządku demokratyczno-liberalnego dotyczy założeń konstruktu technokratycznego, potraktowanego tutaj jako punkt wyjścia do antydemokratycznej degradacji ustrojowej.

Perspektywa ideowo-historyczna dostarcza materii w postaci kontrowersyjnej koncepcji Platona, polegającej na oddaniu całości spraw państwowych w ręce wyselekcjonowanej kasty mędrców - „stróżów doskonałych”

E. Majewska, J. Sowa, Od redaktorów, s. 6.

21 Ch. Mouffe, Paradoks demokracji, Wrocław 2005, s. 35.

${ }^{22}$ H. K. Wells, Pragmatyzm. Filozofia imperializmu, Warszawa 1956, s. 246. 
(sophokracja), wdrażających postulaty inżynierii społecznej. Struktura idealnej polis oparta została w niej na hierarchii wiedzy. Przyszła warstwa rządząca podlegała rygorystycznemu procesowi wychowawczemu, prowadzącemu do ukształtowania elity o antydemokratyczno-komunistycznym charakterze. Natomiast punktem odniesienia dla sprawujących władzę, zdystansowanych wobec pospolitych potrzeb filozofów miały być wskazania rozumu, uzyskujące pierwszeństwo nawet przed kategoriami normatywnymi ${ }^{23}$. Zgodnie z Popperowską wizją to właśnie Platon stanowi częściową personifikację technologa społecznego, który „podchodzi do instytucji racjonalnie, to znaczy jak do środków prowadzących do danych celów, i jak technolog ocenia je w całości zależnie od ich adekwatności, skuteczności, prostoty itp. ${ }^{24}$ Funkcję komplementarną wobec powyższej teorii spełniała Platońska historiozofia $\mathrm{w}$ aspekcie pięciofazowego degeneratywnego cyklu społeczno-kulturowego, (arystokracja - timarchia/timokracja - oligarchia - demokracja - tyrania) zdeterminowanego naturą rządzących, a konkretnie ich typem osobowości (duszy). Nieuchronność regresu polis rekompensowana zostaje częściowo „przez osiągnięcia nauki i kultury materialnej”; dewolucja ustrojowopolityczna nie jest każdorazowo zupełna ${ }^{25}$. Jednak, jak twierdzi Ch. Mouffe: „Sytuacja, w której system różnic zostałby tak doskonale i ostatecznie scalony, oznaczałaby kres hegemonicznej formy polityki. Istniałyby wówczas relacje podporządkowania bądź władzy, lecz nie relacje hegemoniczne w sensie ścisłym" ". Trwałe zamknięcie pluralistycznego uniwersum, gwarantowanego przez współczesne demokracje liberalne, skutkowałoby jednocześnie zniszczeniem platformy, na której dokonuje się renegocjacja dyskursów rozmaitej proweniencji. Tego rodzaju „zamknięcie” byłoby znamienne dla Platońskiej idei państwa, reprezentującej właśnie cechy merytokratyczne.

\footnotetext{
J. Baszkiewicz, F. Ryszka, Historia doktryn politycznych i prawnych, Warszawa 1984, s. 45-51; K. Chojnicka, H. Olszewski, Historia doktryn politycznych i prawnych, Poznań 2004, s. 22-25; L. Dubel, Historia doktryn politycznych i prawnych do schylku XIX wieku, Warszawa 2005, s. 5763; K. Grzybowski, Historia doktryn politycznych i prawnych. Od państwa niewolniczego do rewolucji burżuazyjnych, Warszawa 1968, s. 52-57; H. Izdebski, Historia myśli politycznej i prawnej, Warszawa 2007, s. 7-12; G. L. Seidler, Przedmarksowska myśl polityczna, Kraków-Wrocław 1985, s. 115-119. Szerzej na temat przejawów merytokracji w historii ludzkości zob. J. Szacki, Historia myśli socjologicznej. Wydanie nowe, Warszawa 2007; tenże, Spotkania z utopia, Warszawa 2000.

K. R. Popper, Spoleczeństwo otwarte i jego wrogowie, t. I, Urok Platona, Warszawa 2006, s. 34.

M. Wichrowski, Spór o naturę procesu historycznego (od Hebrajczyków do śmierci Fryderyka Nietzschego), Warszawa 1995, s. 23.

E. Laclau, Ch. Mouffe, Hegemonia i socjalistyczna strategia, s. 148.
} 
Jeżeli uznamy merytokrację za system społeczny tudzież polityczny oparty na uznaniu wobec kompetencji i zasług ${ }^{27}$ jednostek albo grup, to nasze dociekania koncentrować się będą wokół funkcji legitymizacyjnej w systemie politycznym, występującej w postaci władzy opartej na „prawdziwej wiedzy", będącej w posiadaniu rządzących (tzw. argumentum ex scienta) ${ }^{28}$. Przedstawiciel tzw. koncepcji kurateli - Robert Dahl - podkreśla dwa niezależne twierdzenia, pisząc, że: „Zgodnie z pierwszym, wiedza o dobru publicznym i najlepszym sposobie jego osiągania jest «nauką», na którą składają się obiektywnie ważne i potwierdzone prawdy; mają one być obiektywne w tym samym stopniu, co prawa fizyki lub (w innym ujęciu) dowody matematyczne. Zgodnie z drugim - wiedzę tę posiąść może tylko znikoma mniejszość ludzi dorosłych. Jak łatwo zauważyć, nawet prawdziwość pierwszego z tych twierdzeń nie implikuje prawdziwości drugiego. Wystarczy wszakże, by jedno z nich było fałszywe, a wali się cała argumentacja. Dajmy na to, że na wiedzę moralną istotnie składają się twierdzenia obiektywnie ważne. Czyż wyklucza to, by większość osób dorosłych, dzięki odpowiedniemu wykształceniu, poznała na tyle te prawdy, aby zasadnie brać udział w rządzeniu? Platon nie wyjaśnił przekonywająco, dlaczego ową «królewską umiejętność» posiąść mogą jedynie nieliczni” ${ }^{29}$.

W tym miejscu dochodzimy do zagadnienia postawy naukowej, ponieważ założenia Platońskiej utopii nieuchronnie przywołują tematykę związaną z postrzeganiem obiektywnej prawdy, a pośrednio z zastosowaniem określonych kryteriów merytokratycznych (empiria, nauka, koherentność, wiedza). Poniższy schemat stanowiłby uwspółcześnioną wersję tej koncepcji. Jego elementy składowe - zastrzegając niekompletność poniższego zestawienia - wymienia Tad Clements, wskazując na komponenty takie jak:

27 Należy odróżnić pojęcie kompetencji w rozumieniu kryterium wyznaczającego status społeczny jednostki czy grupy od jego ujęcia zaistniałego na gruncie nauk prawnych w postaci możności prawnej, upoważnienia, czyli szczególnego rodzaju sytuacji prawnych generowanych przez tzw. normy kompetencyjne; szerzej zob. A. Bator, Kompetencja w prawie i prawoznawstwie, Wrocław 2004; Z zagadnień teorii i filozofii prawa. Kompetencja ze stanowiska teorii i filozofii prawa, red. W. Jedlecka, Wrocław 2004; Z. Ziembiński, Kompetencja i norma kompetencyjna, „Ruch Prawniczy, Ekonomiczny i Socjologiczny” 1969, z. 4, s. 23-41; tenże, Problemy podstawowe prawoznawstwa, Warszawa 1980, s. 100-101, 160-172, 204-210, 257-260, $322-$ $323,328-334,353,356-360,365-368,417-418,456-458$; tenże, $O$ aparaturze pojęciowej dotyczącej sytuacji prawnych, „Państwo i Prawo” 1985, z. 3, s. 32-47; tenże, O zawilościach zwiąanych z pojmowaniem kompetencji, „Państwo i Prawo” 1991, z. 4, s. 14-24. Koncepcję tzw. zasługi sensu stricto oraz jej wyjątkowe znaczenie omawia W. Sadurski, Teoria sprawiedliwości. Podstawowe zagadnienia, Warszawa 1988, s. 118-121, 153-154. nej wobec merytokracji (zagrożenie wolności, status nierówności, niespójność, niesprawiedliwość) zob. w: S. White, Równość, Warszawa 2009, s. 95-106. 
ciekawość intelektualna, potrzeba posiadania zasadnych przekonań, naturalistyczne pojmowanie zjawisk, nierównoważność pewności psychologicznej z pewnością logiczną i prawdopodobieństwem empirycznym, sceptycyzm, manipulacja ${ }^{30}$, prostota logiczna (zasada ekonomii), klarowność pojęć, neutralność moralna, nieosobowy sposób myślenia o naturze ${ }^{31}$.

Na niebezpieczeństwo deformacji postawy naukowej jako punktu odniesienia merytokratyzmu wskazywali wyraźnie Karl Rajmund Popper oraz Jean François Lyotard, skądinąd czyniąc to z zupełnie przeciwstawnych stanowisk. K. R. Popper dostrzega zagrożenie $\mathrm{w}$,posługiwaniu się subiektywnym sensem wiedzy", co sprowadza naukę do wytworu społeczeństwa, powodując zerwanie z jej „pierwszorzędnymi aspektami”: obiektywnością, prawdziwością, komunikowalnością, sprawdzalnością ${ }^{32}$. Z kolei J. F. Lyotard stwierdza, że nauka zostaje zredukowana „do poziomu ideologii lub narzędzia władzy, jeżeli dyskurs, który miał ją legitymizować, sam okazuje się, podobnie jak prymitywna opowieść, wiedzą prenaukową" ${ }^{33}$.

Już w latach 30. XX wieku Karl Mannheim wskazywał na postępującą syntezę nauki oraz polityki, twierdząc, iż: „stopienie się polityki i myślenia naukowego spowodowało, że coraz bardziej wszelka polityka, przynajmniej w tych formach, w których chciała być widziana z zewnątrz, przyjmowała barwy naukowe i odwrotnie - poglądy naukowe zabarwienie polityczne" ${ }^{34}$. Sprzężenie pomiędzy fenomenami władzy-polityki oraz wiedzy-nauki znakomicie uwypuklił Michel Foucault w swojej koncepcji pandominacjonizmu, stwierdzając dobitnie: „Ani władza nie może być praktykowana bez wiedzy, ani wiedza nie może nie płodzić władzy" ${ }^{35}$.

30 Tzn. skłonność do stawiania naturze pytań w formie alternatywy i aranżowania warunków, które zmuszają ją do jednoznacznych odpowiedzi. Skłonność ta sprawia, że uczeni preferują kontrolowane obserwacje i eksperymenty, a także inne wypróbowane i zaakceptowane w nauce procedury, odrzucają natomiast jako niezadowalające wyjaśnienia anegdotyczne i procedury nie kontrolowane we właściwy sposób.

31 T. Clements, Nauka kontra religia, Warszawa 2002, s. 51-52; więcej na temat kontrowersyjności pojęcia tzw. światopoglądu naukowego zob. w: M. Szyszkowska, Czy światopogląd może być naukowy? Analiza filozoficzna, „Życie i Myśl” 1971, nr 11, s. 67-75.

32 A. Jabłoński, Status teoretyczny i funkcja techniczna wiedzy o społeczeństwie. Wokót myśli Karla R.Poppera i Józefa M. Bocheńskiego, Lublin 2002, s. 55-91. J. F. Lyotard, Kondycja ponowoczesna, Warszawa 1997, s. 113.

K. Mannheim, Ideologia i utopia, Lublin 1992, s. 30.

Cyt. za: A. Szahaj, M. N. Jakubowski, Filozofia polityki, Warszawa 2005, s. 153; zob. też E. Bińczyk, Michel Foucault, nieklasyczna socjologia wiedzy oraz perypetie władzy - wiedzy, „Dyskurs” 2007, nr 5, s. 111-123; B. Błesznowski, Batalia o czlowieka. Genealogia władzy Michela Foucault jako próba wyzwolenia podmiotu, Warszawa 2009, s. 82-93; M. Żyromski, Socjologia wiedzy Michela Foucault. Koncepcja władza - wiedza, [w:] Teoretyczne podstawy socjologii wiedzy, t. I, red. P. Bytniewski, M. Chałubiński, Lublin 2006, s. 264-270. 
Idee technokratyczne, przemycane często w programach politycznych lat 60 . oraz 70. ubiegłego wieku, były wynikiem gwałtownego rozwoju technologicznego w kręgu demokracji zachodnich ${ }^{36}$. Nie oznacza to jednak, że w obecnej, silnie stechnologizowanej przestrzeni społeczno-gospodarczej stare idee nie mogą odnaleźć swojego miejsca. Naukowy typ zarządzania, uzależniony wyłącznie od zastosowania technologicznych środków realizacji, tłumi skostniałe formy polityki pojmowanej jako metoda organizacji przestrzeni państwowej. „Ideologia technokratycznej kontroli opiera się na zwiększeniu roli wiedzy i doświadczenia technicznego, przy założeniu, że wymogi techniczne wyparły formy tradycyjnej polityki w podejmowaniu decyzji organizacyjnych i zarządzaniu" ${ }^{\text {"37 }}$. Utrwalone formy uprawiania polityki odchodzą więc do lamusa wobec rzeczywistości społecznej, która w coraz większym stopniu uzależnia pozytywne rozstrzygnięcie problemów od władzy eksperckiej, będącej synonimem profesjonalizmu oraz sukcesu. Społeczne mniemanie, iż eksperckie metody działania są najlepszym sposobem radzenia sobie z otaczającą rzeczywistością, sprawia, iż stają się one „potężnym narzędziem legitymizacji władzy ekspertów”" . Niebezpiecznie toksyczny dla demokracji proces legitymizacji współczesnej elity eksperckiej sprzyja dezawuowaniu polityki, kojarzonej w coraz większym stopniu z kompromitującym brakiem kompetencji w zakresie zarządzania strukturami państwa. Negatywnie postrzegana polityka utożsamiona zostaje zarówno z elementami uzasadniającymi niewydolne przejawy zastanej rzeczywistości politycznej, jak i siłami zagrażającymi tworzeniu się nowej wizji ładu technologicznego.

Konstrukcja świata oparta na formach stechnologizowanej, a zarazem niepolitycznej struktury państwa obecna była szczególnie w Stanach Zjednoczonych w latach 30 . XX wieku, a to za sprawą ruchu technokratów, którzy „przedkładali «rządy nauki» nad «rządy człowieka» i zalecali utworzenie ogólnokrajowego gremium - technetu - które byłoby upoważnione do dysponowania zasobami kraju i podejmowania decyzji dotyczących produkcji i dystrybucji dóbr i usług wedle kryterium najbardziej efektywnego wykorzystania kapitału naturalnego, ludzkiego i maszyn" ${ }^{39}$. Gloryfikowanie nowej, technologicznej rzeczywistości przez amerykańskie społeczeństwo zaowocowało powstaniem nurtu technokratycznego, cieszącego się nie spotykanym nigdy przedtem poparciem społecznym. Neil Postman wymie-

\footnotetext{
V. Dusek, Philosophy of Technology. An Introduction, Oxford 2006, s. 48.

B. H. Burris, Technocracy at Work, Albany 1993, s. 153.

Tamże.

J. Rifkin, Koniec pracy. Schyłek sily roboczej na świecie i początek ery postrynkowej, Wrocław 2001, s. 79.
} 
nia kilka podstawowych przyczyn pojawienia się ruchów technokratycznych w amerykańskich realiach. Zalicza do nich m.in. pochwałę wszelkiej nowości tożsamą z „ideą udoskonalenia”, dynamizm kapitalizmu wykorzystującego wielkie możliwości technologiczne, a także „sukcesy dwudziestowiecznej techniki, dostarczającej Amerykanom wygód, komfortu, szybkości", co w powszechnym mniemaniu uniemożliwiało istnienie, a zarazem usprawiedliwiało bezprzedmiotowość poszukiwań ,jakichkolwiek innych źródeł spełnienia, możliwości twórczych czy celu" ${ }^{40}$. Tak krytykowane przez Michaela Oakeshotta, „zarażone” racjonalizmem formy polityki ${ }^{41}$, będące synonimem technokratycznych struktur władzy, okazały się nadzwyczaj popularne w zachodnich demokracjach liberalnych. Dyskurs technokratyczny zdołał zbudować zatem silną pozycję, wyrastając na żyznym podłożu demokratycznoliberalnego agonizmu - zgodnie z koncepcją Ch. Mouffe - dopuszczającego wielość form hegemonicznych. Negujący wartości demokratyczne autorytarny dyskurs technokratyczny, forsujący utopijne formy organizacji rzeczywistości społeczno-gospodarczej, zdołał zawłaszczyć znaczną sferę ludzkiej świadomości. Koncepcje technokratyczne w Stanach Zjednoczonych wygasały dopiero, kiedy nadmierna wiara w technologię załamała się pod ciężarem własnej niedoskonałości, a synonimem tego zjawiska były wielkie katastrofy-symbole, takie jak awaria elektrowni atomowej na wyspie Three Mile, wybuch w Czarnobylu oraz katastrofa promu "Challenger" ${ }^{\text {" }}$. Zagrożenie sfery publicznej technokratyzacją dostrzega Andrzej Szahaj, pisząc: „żaden system efektywnego działania społecznego nie może obejść się bez pewnej dozy zachowań technokratycznych. A jednak... A jednak technokracja jest niebezpieczna. Wtedy szczególnie, gdy chce swój styl działania narzucić całej wspólnocie politycznej, gdy wymyka się spod kontroli i zaczyna stano-

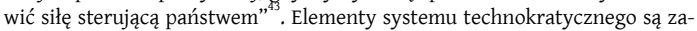
tem składnikiem każdego systemu politycznego, jednak - jak staraliśmy się tutaj wykazać - demokracja liberalna gwarantująca pełnowymiarowy pluralizm polityczny jest być może szczególnie narażona na nowe niebezpieczne tendencje technokratyczne. Czerpiąc bowiem obficie z pokaźnego dorobku technologii, może zachłysnąć się, jak uczyniło to społeczeństwo amerykańskie lat 30. XX w., nowymi wizjami świata wolnego od „trującego elementarium politycznego".

N. Postman, Technopol. Triumf techniki nad kultura, Warszawa 1995, s. 66-68.

M. Oakeshott, Wieża Babel i inne eseje, Warszawa 1999, s. 41.

J. Rifkin, Koniec pracy, s. 80.

A. Szahaj, Zniewalająca moc kultury. Artykuły i szkice z filozofii kultury, poznania i polityki, Toruń 2004 , s. 252. 
Zarysowane powyżej zagadnienia (kryzys demokracji liberalnej oraz doktryny neoliberalnej, ekspansywność naukowo-technologicznych form rzeczywistości, polityczna instrumentalizacja nauki, agonistyczna platforma artykulacji dyskursów) stanowią podstawę wyjściową do rozwoju kontrhegemonicznego dyskursu technokratycznego. Koncepcje zaistniałe w przeszłości na gruncie amerykańskim były zagrożeniem demokratycznoliberalnego porządku, ponieważ w znacznym stopniu wykorzystywały możliwości ekspresji gwarantowane przez demokratyczny pluralizm. Nie oznacza to, iż demokracja nie powinna korzystać z progresji zapewnianej przez naukowy ogląd świata. Jednocześnie nie może sobie pozwolić na niedostrzeganie zagrożeń płynących z instrumentalizacji lub też ideologizacji postawy naukowej. Zadaniem demokracji liberalnej jest $\mathrm{w}$ tej perspektywie przede wszystkim zapobieżenie motywowanym technologiczną racjonalnością deformacjom, wprawiającym w ruch spiralę autodestrukcji. Demokracje liberalne powinny korygować własny rozwój, aby ponownie aktualne nie stały się słowa przywódcy ideowego nowej lewicy lat 60. XX wieku, Herberta Marcuse'a: „w środowisku technologii kultura, polityka i ekonomia zlewają się we wszechobecny system, który pochłania i odrzuca wszystkie alternatywy. Wydajność i wzrost możliwości tego systemu stabilizują społeczeństwo i utrzymują postęp techniczny w obrębie struktury panowania. Technologiczna racjonalność staje się racjonalnością polityczną",

TOMASZ B ORG UL, TOMASZ PANEK

44 H. Marcuse, Czlowiek jednowymiarowy. Badania nad ideologią rozwiniętego spoleczeństwa przemysłowego, Warszawa 1991, s. 13. Na temat funkcji scjentyzmu, gloryfikującego i racjonalizującego cywilizację naukowo-techniczną zob. L. Nowak, Byt i myśl, t. I, Nicość i istnienie, Poznań 1998, s. 60 i n.; szerzej zob. A. Lekka-Kowalik, Odkrywanie aksjologicznego wymiaru nauki, Lublin 2009; W. Lang, Moralne aspekty rewolucji naukowo-technicznej, „Człowiek i Społeczeństwo" 1972 , nr 11-12, s. 104-143. 


\section{Abstract}

The purpose of the present article is an analysis of liberal democracy's threats in context of alternative discourses (meritocracy, technocracy) towards liberal values. The legitimization of these options is conditioned by the critical situation of hitherto existing politico-economic model. It may create a source of various instabilities menacing the ideological „order”. This ideological transformation would bring to negating the liberal system and its values in favour of solutions reorganizing not only a category of political system, but also a social way of thinking about reality.

Crucial factors which determine that crisis are following: the global economic recession caused by "infallible" doctrine of neoliberalism, the successive erosion of national state construct, the expansiveness of scientifico-technological reality's forms, the political instrumentalization of science, the agonistic platform of discourses' articulation. Above-mentioned elements make basis for a counterhegemonic ideas' development, that is „pragmatic” technocracy and „ideologically advanced" meritocracy.

Technocracy claims rise of a new power's type and socio-political system, where prominent experts (economists, managers, sociologists, technicians) would play decisive part. Specialist knowledge in composition with occupying positions, in which it finds application, would be a criterion of access to power. On the contrary, meritocracy is a definite socio-political system (postulated or real), within the frameworks of which individuals' social status is achieved owing to an inborn intellectual potential and merits' contribution; the control over public life is entrusted to the best prepared persons and/or groups. In this range, the archetypical project was Plato's utopia, consisting in charging the entireness of state's matters to selected sages' caste - ,the perfectwatchmens" (sophocracy), initiating the postulates of social engineering (the so-called argumentum ex scienta - authority's legitimization based on „true knowledge").

Described conceptions were as well potentially destructive for democracy's structures, because they utilize possibilities of expression guaranteed in the democratic, pluralistic public sphere. It does not mean that democracy should not have the use of progress provided by the scientific world's outlook. Simultaneously, it cannot afford to non perceiving threats resulted from instrumentalization or ideologization of scientific attitude. Liberal democracies should correct their own development and eliminate deformities, caused by technological rationality in order to avoid the situation when "technological rationality becomes political one” (Herbert Marcuse). 